\title{
Mud volcanoes and methane seeps in Romania: main features and gas flux
}

\author{
Calin Baciu $\left({ }^{1}\right)$, Antonio Caracausi $\left({ }^{2}\right)$, Giuseppe Etiope $\left(^{3}\right)$ and Francesco Italiano $\left({ }^{2}\right)$ \\ (1) Babes-Bolyai University, Faculty of Environmental Sciences, Cluj-Napoca, Romania \\ ${ }_{\left({ }^{2}\right)}$ Istituto Nazionale di Geofisica e Vulcanologia, Sezione Palermo, Italy \\ $\left.{ }^{3}\right)$ Istituto Nazionale di Geofisica e Vulcanologia, Sezione Roma 2, Italy
}

\begin{abstract}
Romania is one of the European countries with the most vigorous natural seepage of methane, uprising from pressurised natural gas and petroleum reservoirs through deep faults. The largest seepage zone is represented by large mud volcanoes, with $\mathrm{CH}_{4}>80 \% \mathrm{v} / \mathrm{v}$, occurring on the Berca-Arbanasi hydrocarbon-bearing faulted anticline, in the Carpathian Foredeep. Smaller mud volcanoes have been identified in other areas of the Carpathian Foredeep, in the Transylvanian Depression and on the Moldavian Platform. New surveys carried out in Transylvania allowed us to discover the richest $\mathrm{N}_{2}$ mud volcano zone in the world $\left(\mathrm{N}_{2}>90 \% \mathrm{v} / \mathrm{v}\right)$, with a remarkably high $\mathrm{He}$ content and a helium isotopic signature which highlights a contribution of mantle-derived source. The large mud volcanoes are generally quiescent, with rare explosive episodes and provide a methane flux in the order of $10^{2}-10^{3} \mathrm{t} \mathrm{km}^{-2} \mathrm{y}^{-1}$. Independently from mud volcanism, a remarkable dry macroseepage, however, has been found, with a degassing rate up to three orders of magnitude higher than that of mud volcanoes $\left(i . e .10^{3}-10^{5}\right.$ t $\mathrm{km}^{-2} \mathrm{y}^{-1}$ ). The total gas flux from all investigated macroseepage zones in Romania is estimated in the range of 1500-2500 t y $\mathrm{y}^{-1}$. The emission from microseepage, pervasively occurring throughout the hydrocarbon-prone basins, has yet to be assessed and added to the total gas output to the atmosphere.
\end{abstract}

Key words mud volcanoes - seeps - methane flux nitrogen - Romania

\section{Introduction}

Romania hosts Europe's largest mud volcanoes and the densest methane-seep population. This seeapage is the result of active compressional tectonics and neotectonics perturbing deep natural gas and petroleum reservoirs, similar to what happens in many other hydrocarbon-prone basins which developed along active and seismic tectonic belts (Link, 1952; Etiope and Klusman, 2002). This natural degassing has been recognised as a

Mailing address: Dr. Calin Baciu, Babes-Bolyai University, Faculty of Environmental Sciences, Str. M. Kogalniceanu 1, 400.084 Cluj-Napoca, Romania; e-mail: calin.baciu@enviro.ubbcluj.ro major source of atmospheric methane (Etiope and Milkov, 2004). There is an extensive scientific literature describing the origin, distribution and characteristics of mud volcanoes (e.g., Kopf, 2002 and references therein). Dry-seeps, normally independent from mud volcanism, are less investigated even though they are quite widespread in faulted sedimentary basins.

All macro-seeps are generally $\mathrm{CH}_{4}$-dominant ( $>90 \% \mathrm{v} / \mathrm{v}$ ), with low $\mathrm{CO}_{2}$ and $\mathrm{N}_{2}$ concentrations and generally low ${ }^{3} \mathrm{He} /{ }^{4} \mathrm{He}$ ratios, indicating the absence of significant gaseous contributions from the mantle (Etiope et al., 2004a; Yang et al. 2003): most of the gas seeps, especially mud volcanoes, are generated along accretionary prisms dominated by crustal sediment sources. Those seeps having a high $\mathrm{N}_{2}$ and low $\mathrm{CH}_{4}$ content (Motyka et al., 1989; Baylis et al., 1997) are quite rare and considered unusual.

In this paper we overview the main features of mud volcanoes and other macro-seeps in Ro- 
mania, expand the data-set on gas flux to the atmosphere, investigated for the first time in 2001 (Etiope et al., 2004a), and show new unusual geochemical data from a mud volcano in Transylvania.

\section{Geotectonic setting of gas emitting areas in Romania}

On the territory of Romania the corresponding part of the Carpathian belt was primarily built due to the interactions of three major geotectonic units: the Intra-Alpine micro-plate (IAP), the East European Plate (EEP), and the Moesian micro-plate (MP). IAP is overlaid by the Transylvanian Depression, the Pannonian Depression and the Carpathian Belt (fig. 1). The south-western part of EEP (the Moldavian Platform) forms the basement of north-eastern Romania. EEP and IAP are separated by a NWSE compression limit - the Tornquist-Teisseyre zone. Major crustal faults delimit the Moesian micro-plate from IAP and EEP. The triple junction of the plates corresponds to Vrancea zone, an active seismic and geodynamic area.

The folded units of the Carpathian arch were generally formed during Alpine orogenesis. The mountainous chain consists of three branches: the Eastern Carpathians, the Southern Carpathians, and the Apuseni Mountains, encircling the Transylvanian Depression filled with Tertiary sediments. In its external part the Carpathian Chain is surrounded by thick molassic deposits belonging to the foredeep. Based on geological and tectonic features the foredeep is divided into several basins (Linzer et al., 1998). The Moldavian Basin, situated on the western margin of EEP, contains a 3000-m thick pile of sediments. The southern half of Eastern Carpathians is bordered by the Focsani Basin, filled with Neogene sediments, with a thickness up to $8000 \mathrm{~m}$. The Getic Basin, situated between the northern margin of the Moesian Plate and the Southern Carpathians consists of Neogene sediments up to 3000-m thick. Important oil and gas reservoirs were identified and exploited in the Carpathian Flysch zone and foredeep, on the Moessian Platform, and in a lesser extent on the Moldavian Platform. The
Flysch zone and Carpathian Foredeep are the classical Romanian oil and gas-producing areas. More than 110 hydrocarbon fields located on these structural units yielded the most of the total amount of oil extracted over the last 150 years in Romania. The age of the hydrocarbonbearing deposits is Paleogene to Pliocene. On the Moessian Platform, more than 125 oil and gas-bearing structures are known, distributed over a very large stratigraphic range, from Devonian to Pliocene, at depths from $350 \mathrm{~m}$ to almost 4900 m (Paraschiv, 1979). On the western side of the Moldavian Platform, some gas-bearing reservoirs were found at the Middle-Upper Miocene level.

The Transylvanian Depression, superimposed on Cretaceous nappes, contains a Paleogene sequence, well developed on its northwestern margin, followed by Neogene deposits with a maximum thickness of about $6000 \mathrm{~m}$. Unlike the adjacent Pannonian Basin, the Transylvanian Basin has some important peculiarities: a very low heat flow, a relatively thick crust, and a relatively high mean altitude (Huismans et al., 1997). Methane emissions are related to natural gas fields that make the Transylvanian Basin one of the most important gasproducing areas in Central and Eastern Europe. Gas reservoirs are generally located in domeshaped anticlines, at the level of Middle-Upper Miocene detritic sequences. More than 75 gasbearing structures were identified. A strong salt horizon, Middle Miocene (Langhian) in age, underlies the productive complex. Since then, no oil has been found in the Neogene Transylvanian Basin.

Mud volcanoes and dry macro-seeps are relatively abundant in Romania, and were identified along the compressive external margin of the Carpathian Chain (the Carpathian Foredeep), the Transylvanian Depression, and the Moldavian Platform (fig. 2). Below we describe the Carpathian manifestations, already analysed in 2001 (Etiope et al., 2004a) and the Transylvanian seepage with new geochemical data acquired in 2002 and 2004. On the Moldavian Platform small bubbling pools and mud volcanoes, related to Neogene gas reservoirs, were identified in some locations, but they still need to be investigated. 


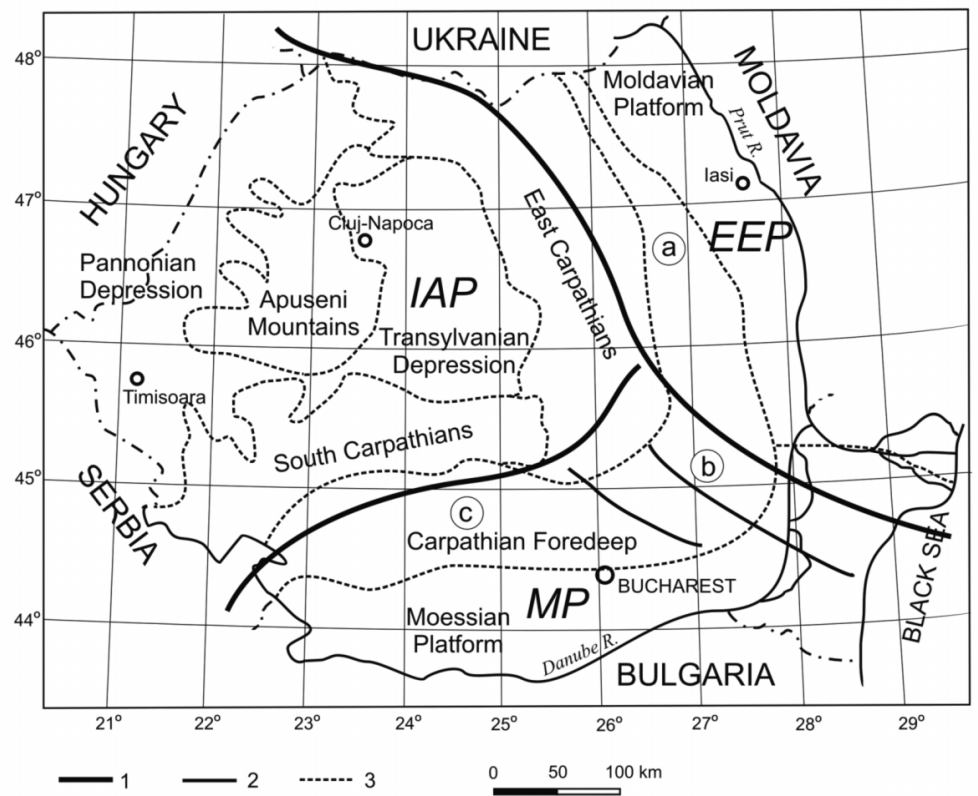

Fig. 1. Geotectonic units in Romania: 1 - limits between lithosperic plates (microplates); 2 - major faults; 3 limits between main structural units; EEP - East European Plate; IAP - Intra-Alpine Microplate; $M P$ - Moessian Microplate; a - Moldavian Basin; b - Focsani Basin; c - Getic Basin.

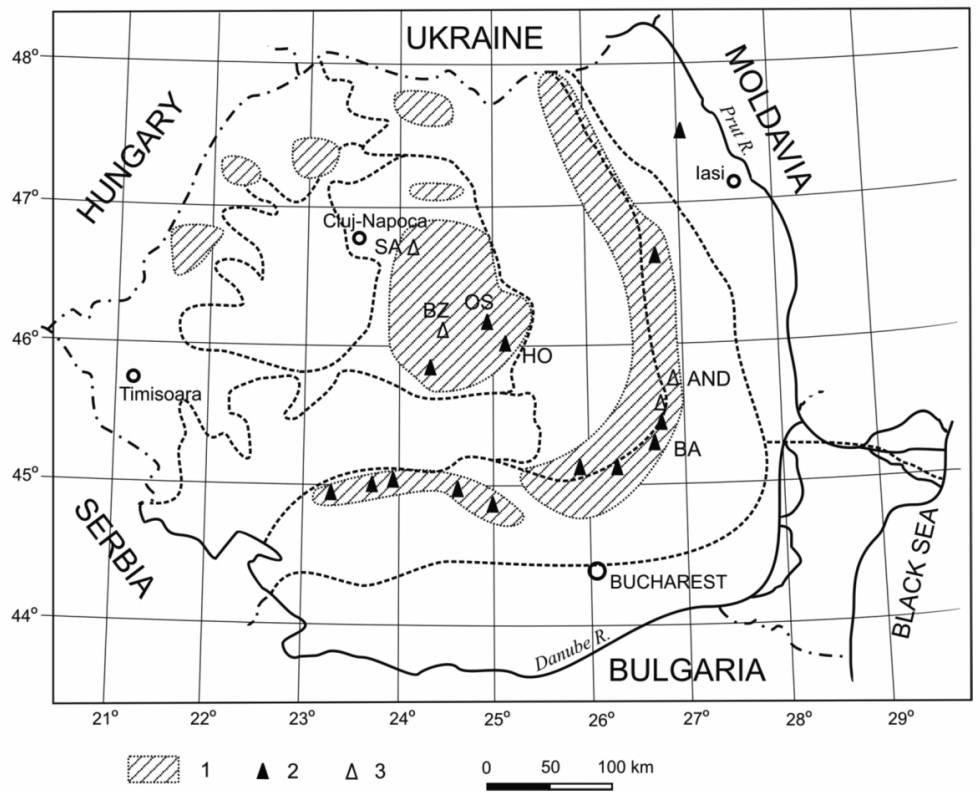

Fig. 2. Distribution of mud volcanoes and hydrocarbon seeps in Romania. 1 - hydrocarbon seepage areas; 2 - mud volcanoes; 3 - Dry macroseeps; $A N D$ - Andreiasu; $B A$ - Berca-Arbanasi hydrocarbon-bearing structure; $B Z$ - Bazna; $H O$ - Homorod; OS - Odorheiu Secuiesc; SA - Sarmasel (redrawn from Paraschiv, 1984; Baciu and Etiope, 2005). 


\section{Features of the main mud volcanoes and methane emissions in Romania}

\subsection{Carpathian Foredeep}

The largest mud volcanoes in Romania are located on the Berca-Arbanasi hydrocarbon-bearing structure in the Carpathian Foredeep (fig. 2) close to the bending zone of the Carpathian belt. Four mud volcano fields are active: Paclele Mari, Paclele Mici, Fierbatori and Beciu. From a structural point of view, the site is located on the inner side of the foredeep, which consists of Miocene molassic sediments. The four gas emitting areas are placed on an $18 \mathrm{~km}$ long anticline fold with salt core, approximately north-south oriented, and disturbed by a system of longitudinal and transversal faults (Etiope et al., 2004a). The structure hosts an important oil and gas reservoir. These mud volcano fields have subcircular or elliptical shaped convex plateaus, covered by products of recent or more ancient activity. On Paclele Mari and Paclele Mici, situated approximately in the middle of the anticline, the active seepage areas are located on the top of two truncated coneshaped hills (fig. 3a). Paclele Mari hill is about $1.8 \mathrm{~km}$ long, $1.3 \mathrm{~km}$ wide and $80 \mathrm{~m}$ high, with an area covered with mud volcano products of 1.62 $\mathrm{km}^{2}$. The active mud volcano field is $0.22 \mathrm{~km}^{2}$ wide. Paclele Mici hill is smaller, about $1.3 \mathrm{~km}$ long, $1.0 \mathrm{~km}$ wide, $60 \mathrm{~m}$ high, and the active mud volcano surface of $0.16 \mathrm{~km}^{2}$, on a total area covered with ejecta of $0.62 \mathrm{~km}^{2}$ (Sencu, 1985). On Paclele Mari and Paclele Mici, mud is generally ejected from conical edifices up to $10 \mathrm{~m}$ high, with an apical vent, and, in some cases, smaller gryphons on the flanks (fig. 4). The slope of the cone is variable, from almost horizontal to a maximum of $35-40^{\circ}$, depending on the viscosity of mud. Other characteristic structures are circular pools filled with muddy water (salse), 3 to $10 \mathrm{~m}$ in diameter (fig. 4). The released waters are salty, bromide-rich (Vaselli et al., 2002), and the variation of TDS values measured at different discharges suggests mixing processes between connate and meteoric water. A thin layer of crude oil, together with dark oxidised petroleum products, may float at the surface of the pool. The activity

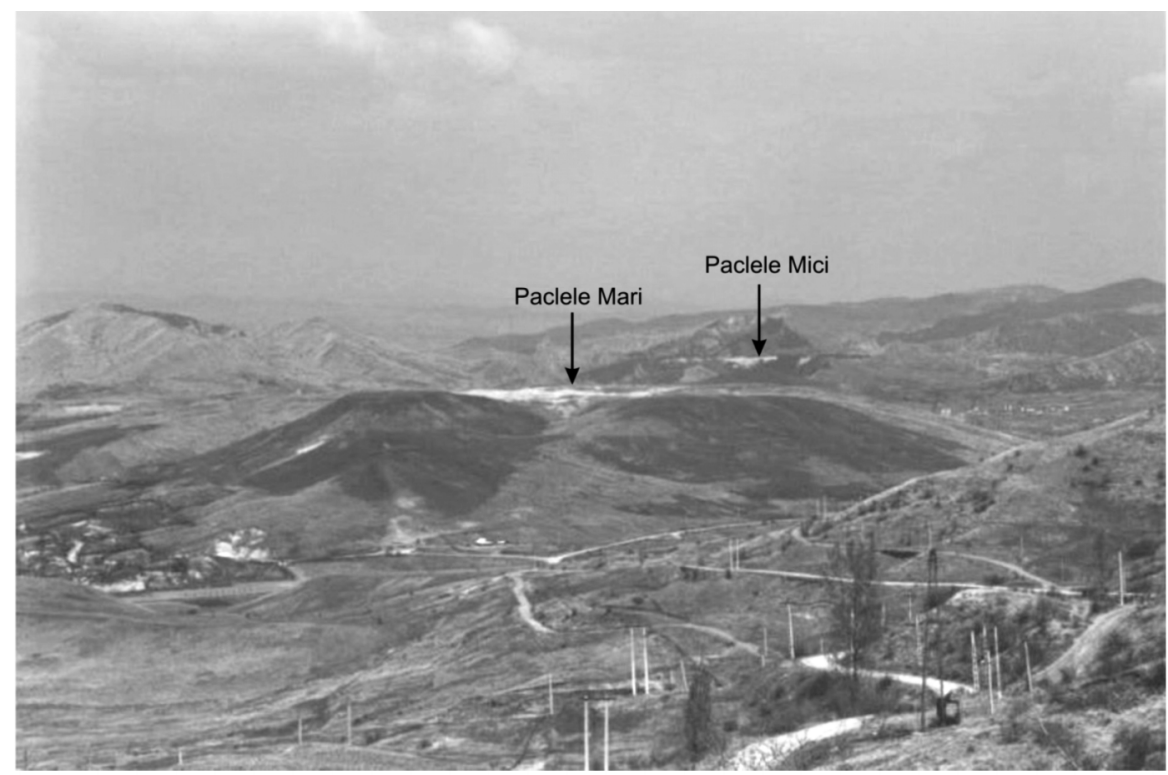

Fig. 3. Perspective of Paclele Mari and Paclele Mici mud volcanic plateaus - Berca-Arbanasi hydrocarbonbearing structure. 

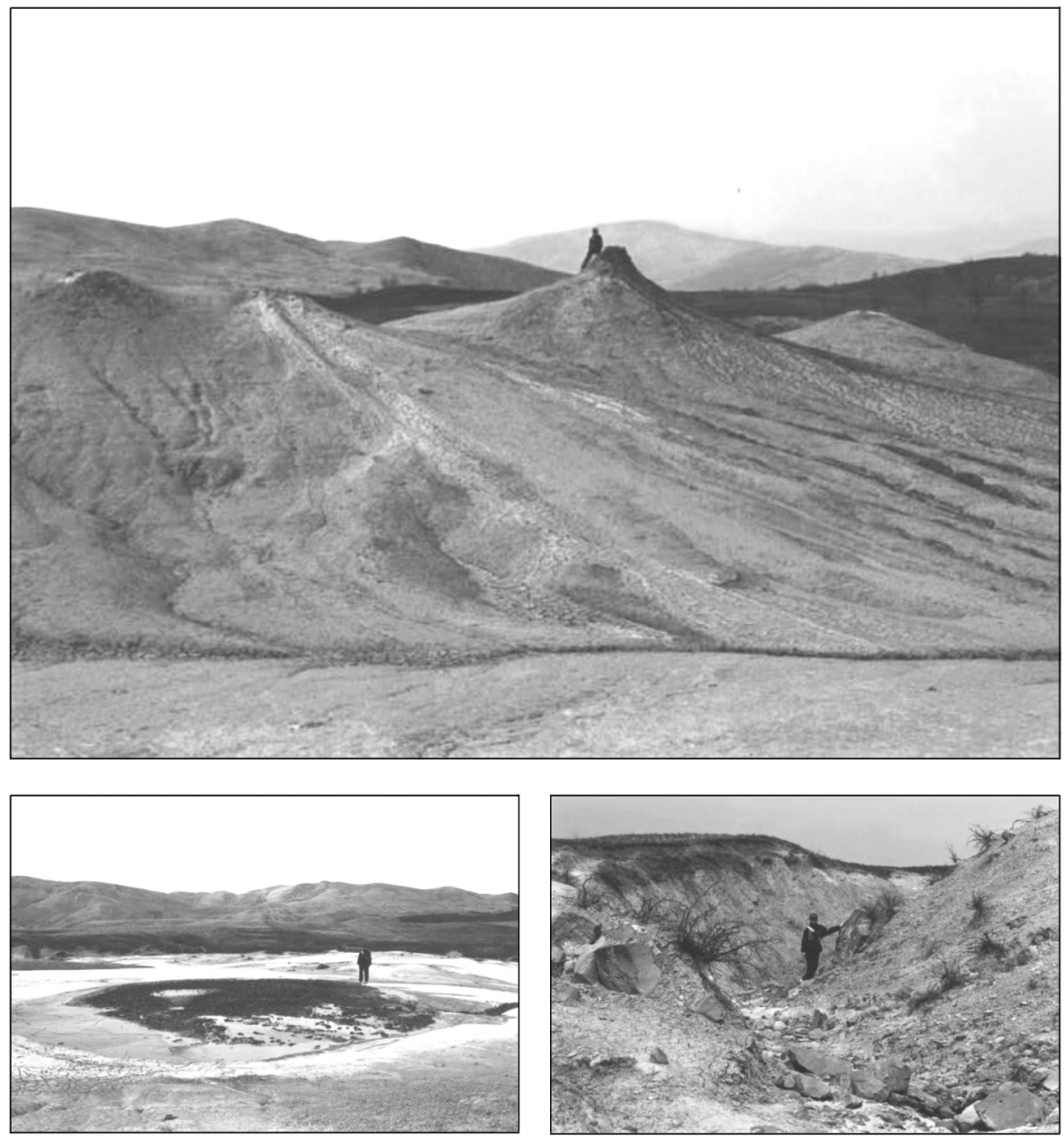

Fig. 4. Paclele Mari mud volcano: (top) mud emitting gryphons; (bottom left) pool with bubbling gas and low viscosity mud-petroleum oxidation products floating at the surface; (bottom right) large blocks of sandstone ejected by mud volcano's ancient activity.

of the mud volcanoes generally consists of a continuous gas bubbling and water overflow from salses, and rhythmical small eruptions of mud from vents. Sandstone and limestone blocks, more than $1 \mathrm{~m}^{3}$ in volume, scattered on the distal sides of the plateaus, document a more violent activity in the past (fig. 4). Fierbatori mud volcano is located in the southernmost part of the anticline, close to Berca. The total area covered with ejecta is about $0.09 \mathrm{~km}^{2}$. Mud is very fluid in this area, and consequently only salses and some flat cones with muddy water pools occur. However methane degassing from the dry soil is very high. A small surface, less than $0.01 \mathrm{~km}^{2}$, with pools of low viscosity bubbling mud, is also present in Beciu area, in the northern extremity of the anticline.

The total surface occupied by recent or ancient mud volcanic products on Berca-Arbanasi hydrocarbon-bearing structure is about $2.5 \mathrm{~km}^{2}$, and the total methane output was estimated as be- 
ing at least 1200 tons per year (Etiope et al., 2004a). All surveys showed that a significant gas microseepage also occurs far from the craters and vents, along the flanks of the mud volcano hills.

The mud volcanoes from Berca-Arbanasi area, especially Paclele Mari and Paclele Mici, have something in common with the «Dashgyl type» of Azerbaijan's mud volcanoes (Hovland et al., 1997; Etiope et al., 2004b):

- Large dimension dome-shaped bodies, reaching hundreds of meters to kilometres in diameter, and tens to hundreds of meters in height, resulted from long-term activity, probably more violent in the past; however, the size of Paclele mud volcanoes is smaller compared to the giant structures of Azerbaijan.

- Relatively small cones (generally a few meters, sometimes more than $10 \mathrm{~m}$ high) distributed on a plateau consisting of ejecta.

- Continuous quiescent activity of vents and weak eruptions.

There is a small plateau with intensive degassing phenomena about $50 \mathrm{~km}$ north of Berca, near Andreiasu village. Everlasting fires with up to 1-m high flames, and some small bubbling pools, 20 to $50 \mathrm{~cm}$ in diameter, can be observed. An important tectonic discontinuity (Casin-Bisoca Fault) seems to provide the pathway for the gas flux to the surface. The type of rocks in the area (hard marls, sandstones, volcanic tuffs) does not allow generation of mud, and consequently only dry gas emissions and relatively clear water bubbling pools are present. The high methane emission area is about $400 \mathrm{~m}^{2}$ wide, and a total flux of about 50 tons per year was estimated (table II).

Some other seeps occur on the western side of the Carpathian Foredeep; they refer to small pools with bubbling fluid mud and cones, generally not exceeding a height of $1 \mathrm{~m}$ (Peaha, 1965). They are still to be investigated.

\subsection{Transylvanian Depression}

In the Transylvanian Depression (figs. 1 and 2) methane emissions are produced by smaller mud volcanoes and dry-seeps (everlasting fires). Sarmasel and Homorod are the two main seepage areas.
Sarmasel is one of the most important gasbearing structures in the Transylvanian Basin. A large gas deposit is located in an oval-shaped dome, slightly elongated on the north-south direction. Fifteen productive horizons were identified on the first $2000 \mathrm{~m}$ of depth, overlying a 900$m$ thick salt layer (Paraschiv, 1979). The age of the sedimentary sequence is Badenian-Sarmatian (Middle Miocene). The presence of natural gas in Transylvania was accidentally discovered here in 1909, when a drill rig searching for potassium salts was blown up when it reached the gas-bearing strata. According to local people, in the 1920s a gas well exploded, producing a crater tens of meters deep. The hole was filled with earth by local people to extinguish the fire and to stop the gas outflow. Due to the permeability of the filling material, the gas has continued to leak slowly and burn for the last 80 years.

Homorod is located near the eastern margin of the Transylvanian Basin, outside the area with known gas fields. The closest gas-bearing structures are Beia (about $15 \mathrm{~km} \mathrm{~N}$ ) and $\mathrm{Bu}-$ nesti (about $15 \mathrm{~km} \mathrm{NW}$ ). A small mud volcano consisting of an inactive cone and four bubbling pools was investigated.

Some smaller or less active mud volcanoes were identified in Western Transylvania, between Turda and Ocna Sibiului, in central-eastern Transylvania (around Odorheiu Secuiesc), and in some other isolated spots. They rarely exceed 1 or $2 \mathrm{~m}$ in height, and $10 \mathrm{~m}$ in diameter. Small pools filled with muddy water and marshy areas with a weak gas bubbling activity were also observed.

\section{Field surveys and analytical techniques}

Two surveys were performed in 2002 and 2004 in the Transylvanian Basin, aimed to detect methane seepage from the soil, measure its flux into the atmosphere, and assess the gas composition and its origin. The investigated areas are the Sarmasel seep, the small mud volcano of Homorod and the Bazna well area.

During the two field campaigns gas samples were collected from the vents and analysed in laboratory for $\mathrm{CH}_{4}, \mathrm{CO}_{2} \mathrm{~N}_{2}$ and $\mathrm{He}$ by Perkin Elmer 8500 gas-chromatograph equipped with a 
$4 \mathrm{~m}$ Carbosieve 5A column and double-detector (Flame Ionization Detector and hot wire detector). Isotopic analyses of ${ }^{3} \mathrm{He} /{ }^{4} \mathrm{He}$ were also performed as described in Etiope et al. (2003). The diffuse soil degassing was measured by the closed-chamber method (Etiope et al., 2004a). Gas accumulated in the chambers was collected two or three times by syringes following time intervals from $20 \mathrm{~s}$ to $10 \mathrm{~min}$ from the box emplacement, and analysed by gas chromatography with micro-TCD detector. On the Homorod mud volcano, the number, size and frequency of the bubble trains were recorded in all the pools and gryphons; the gas flux was then estimated using a theoretical plot of bubble flux versus bubble size versus bubble frequency (Etiope et al., 2004a).

The output from microseepage is estimated by averaging field contribution from identifiable homogeneous areas, with calculations of the type

$$
E_{\text {micro }}=A \times\langle F\rangle
$$

where $A$ is the area $\left(\mathrm{km}^{2}\right.$ or $\left.\mathrm{m}^{2}\right)$ and $\langle F\rangle$ is the average flux $\left(\mathrm{t} \mathrm{km}^{-2} \mathrm{y}^{-1}\right.$ or $\left.\mathrm{mg} \mathrm{m}^{-2} \mathrm{~d}^{-1}\right)$.

The definition of the area used for emission calculation depends on the recognition of homogeneous identifiable areas and the spatial variability of the measured flux.

During the 2004 survey an innovative method was used for detecting methane seepage, based on a portable laser sensor, able to detect methane anomalies in the air ( $>2$ ppmv) a few centimeters above the soil, by hand-scanning a laser beam along tens of meters in the field. The instrument is a portable remote methane detector (Lasermethane ${ }^{\mathrm{TM}}$ SA3C06A, Tokyo Gas Engineering \& Anritsu Corp.) based on infrared laser beam and wavelength modulation absorption spectroscopy (Iseki, 2004). The laser is able to scan from a distance of $1 \mathrm{~m}$ to $150 \mathrm{~m}$ using retro-reflectors, providing the methane column density expressed in ppm $\times m$, with a lower detection limit down to 1.3 ppm $\times m$ (depending on the operating conditions). This kind of measurements has allowed, so far, to scan wide areas in a short time $\left(\mathrm{a} 0.3 \mathrm{~km}^{2}\right.$ field can be scanned within $1 \mathrm{~h}$ ), recognising the existence of microseepage in wide zones, with anomalies up to $40-50 \mathrm{ppmv}$ of methane at $10-20 \mathrm{~cm}$ above the soil.

\section{Results}

\subsection{Gas composition and helium isotopes}

Gas composition and isotopic data are shown in table I. Gas analyses of the Carpathian seeps (Etiope et al., 2004a) are included for comparison. All seeps are $\mathrm{CH}_{4}$-dominant except the gases released in a pool and shalow well at the Homorod mud volcano, which are $\mathrm{N}_{2}$-dominant (93\%) and $\mathrm{CH}_{4}$ is $<0.5 \%$ (fig. 5). Helium content is also extremely high (1.4\%).

The measured ${ }^{3} \mathrm{He} /{ }^{4} \mathrm{He}(\mathrm{R})$ ratios range between 0.01 and $0.4 \mathrm{Ra}\left(\mathrm{Ra}\right.$ is the ${ }^{3} \mathrm{He} /{ }^{4} \mathrm{He}$ in atmosphere, $\left.1.39 \times 10^{-6}\right)$. The highest helium isotopic signature, $R=0.4 \mathrm{Ra}$, was measured in the Homorod gas and the measured ${ }^{4} \mathrm{He} /{ }^{20} \mathrm{Ne}$, higher than 10000 , shows a negligible air contribution.

\subsection{Gas flux}

Gas flux data are summarised in table II. The results are consistent with the surveys performed in other macroseepage zones (e.g., Eastern Romania, Italy and Azerbaijan), where the specific emission factor is always in the range 100-1000 $\mathrm{t} \mathrm{km}^{-2} \mathrm{y}^{-1}$ for mud volcanoes, and above $10^{3} \mathrm{t} \mathrm{km}^{-2} \mathrm{y}^{-1}$ for dry seeps (table III).

The specific flux at Sarmasel is one of the largest in Romania, comparable to that stemming from the other everlasting fire at Andreiasu (Carpathian zone). Anomalous concentrations of $\mathrm{CH}_{4}$ in air, within $1 \mathrm{~m}$ from the ground, were detected throughout a large area around the Sarmasel seep. Anomalies up to 200 ppmv, within $1 \mathrm{~m}$ from the ground, were identified in correspondence with the most intensive seepage zone, characterised by an everlasting fire. Anomalies in the order of 3-20 pp$\mathrm{mv}$, within $50 \mathrm{~cm}$ from the soil, were detected up to 1-2 $\mathrm{km}$ from the seep. Measurements of gas flux from soil proved the existence of microseepage (orders of tens or hundreds of $\mathrm{mg}$ $\mathrm{m}^{-2} \mathrm{~d}^{-1}$ ), widespread over an area of at least about $10 \mathrm{~km}^{2}$. The total output in the surveyed area is about $21 \mathrm{t} \mathrm{y}^{-1}$. Conservatively assuming $10 \mathrm{mg} \mathrm{m}^{-2} \mathrm{~d}^{-1}$ throughout $10 \mathrm{~km}^{2}$, would give a further diffuse emission of $37 \mathrm{t} \mathrm{y}^{-1}$. 
Table I. Gas composition and He isotopes of the macro-seeps in Romania.

\begin{tabular}{lccccc}
\hline \hline \multicolumn{1}{c}{ Sample } & $\mathrm{He}(\mathrm{ppmv})$ & $\mathrm{N}_{2}(\% \mathrm{v})$ & $\mathrm{CH}_{4}(\% \mathrm{v})$ & $\mathrm{CO}_{2}(\% \mathrm{v})$ & ${ }^{3} \mathrm{He} /{ }^{4} \mathrm{He}$ \\
\hline \multicolumn{2}{l}{ Transylvanian Depression } & & & & \\
Homorod (pool) & 14856.8 & 91.5 & 0.3 & 6.7 & \\
Homorod (well) & 14405.5 & 92.6 & 0.4 & 5.6 & $5.9 \times 10^{-7}$ \\
$\quad$ Bazna & 16.5 & 1.0 & 97.9 & 1.2 & $2.8 \times 10^{-8}$ \\
Sarmasel & 27.0 & 0.6 & 98.7 & 0.7 & $2.9 \times 10^{-8}$ \\
Carpathian Foredeep & & & & & \\
Andreiasu & 10.3 & 2.2 & 95.8 & 2.0 & $4.3 \times 10^{-8}$ \\
Paclele Mari & 25.1 & 15.3 & 82.7 & 2.0 & $6.1 \times 10^{-8}$ \\
Paclele Mici & 24.0 & 2.8 & 94.9 & 2.3 & $6.1 \times 10^{-8}$ \\
Fierbatori & 14.3 & 6.2 & 91.3 & 2.5 & $2.1 \times 10^{-8}$ \\
\hline
\end{tabular}

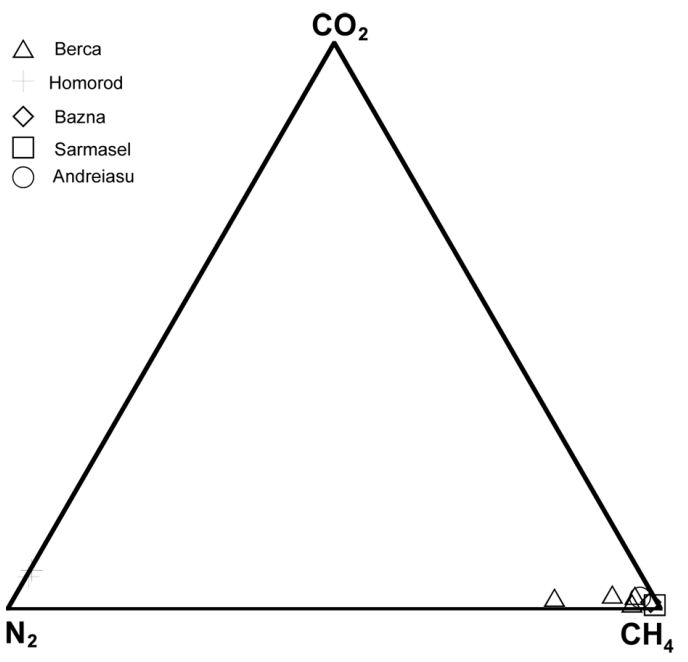

Fig. 5. Characterization of the chemical composition of the free gases sampled in both mud volcanoes and everlasting fires.

The Homorod area shows a lower methane degassing, also because the discharged gas has very low $\mathrm{CH}_{4}$ concentrations.

Further measurements are necessary to estimate the total seepage throughout the Transylvanian Basin (about $15000 \mathrm{~km}^{2}$ ).

\section{Discussion and conclusions}

\subsection{Discovery of an unusual $N_{2}$-dominant mud volcano area}

The $\mathrm{N}_{2}$-rich gas composition of Homorod mud volcano is completely different from other Romanian $\mathrm{CH}_{4}$-dominant seeps. $\mathrm{N}_{2}$-dominant mud volcanoes are known in Papua New Guinea (up to $76 \% \mathrm{v} / \mathrm{v}$; Baylis et al., 1997), and others may occur in areas close to recent magmatic activity (e.g., Alaska; Motyka et al., 1989), but to our knowledge, none of them reaches $\mathrm{N}_{2}$ levels $>90 \%$. So, the Homorod mud volcano seems to be the $\mathrm{N}_{2}$-richest mud volcano in the world. It also shows an astonishing helium concentration $(>1 \%)$ never reported in the gas seeps literature. Such an unusual seep could be related to $\mathrm{N}_{2}$-rich reservoirs, with hydrocarbons depleted in alkanes, generally related to a final stage of gas generation. Gas-bearing structures on the eastern side of the Transylvanian Basin, in fact, show an increased $\mathrm{N}_{2}$ content, 3.5 to $20 \%$, with a maximum value of $57 \%$ (table IV), compared to other areas of the same basin, where it does not exceed 1\% (Filipescu and Huma, 1979). This type of natural gases also occurs, for example, in Germany (Krooss et al., 1995), Russia (Guseva and Fayngersh, 1973), or in the Hugoton-Panhandle giant gas field in the U.S.A. (Ballentine and Sherwood-Lollar, 2002). 
Table II. Methane flux from macro-seeps in Romania and comparison with seeps in Azerbaijan. $M V-$ Mud Volcano; $D S$ - Dry Seep.

\begin{tabular}{cccccccc}
\hline \hline $\begin{array}{c}\text { Country/ } \\
\text { Site }\end{array}$ & $\begin{array}{c}\text { Source } \\
\text { type }\end{array}$ & Area \\
$\left(\mathrm{km}^{2}\right)$ & $\begin{array}{c}\text { Microseepage } \\
\text { output } \\
\left(\mathrm{t} \mathrm{y}^{-1}\right)\end{array}$ & $\begin{array}{c}\text { Vent } \\
\text { output } \\
\left(\mathrm{t}^{-1}\right)\end{array}$ & $\begin{array}{c}\text { Total } \\
\text { output } \\
\left(\mathrm{t} \mathrm{y}^{-1}\right)\end{array}$ & $\begin{array}{c}\text { Specific } \\
\text { flux } \\
\left(\mathrm{t} \mathrm{km}^{-2} \mathrm{y}^{-1}\right)\end{array}$ & References \\
\hline
\end{tabular}

Romania

Carpathian Foredeep

\begin{tabular}{cccccccc} 
Paclele Mici & MV & 0.62 & 128 & 255 & 383 & 618 & Etiope et al. (2004a) \\
Paclele Mari & MV & 1.62 & 430 & 300 & 730 & 451 &, \\
Fierbatori & MV & 0.025 & 20 & 17 & 37 & 1480 &, \\
Andreiasu & DS & 0.0004 & 26 & 24 & 50 & 125000 &, \\
\multicolumn{2}{c}{ Transylvania } & & & & & & \\
Sarmasel & DS & 0.007 & 16 & 5 & 21 & 3000 & This work \\
Homorod & MV & 0.005 & 0.5 & 0.5 & 1 & 200 &, \\
Bazna & DS & 0.002 & 0.4 & - & 0.4 & 200 &, \\
\multicolumn{2}{l}{ Total measured } & 2.3 & & & 26 & &
\end{tabular}

Azerbaijan

\begin{tabular}{cccccccc} 
Lokbatan & MV & 2.98 & 139 & - & 342 & 115 & Etiope et al. (2004b) \\
Kechaldag & MV & 0.77 & 90 & 4 & 94 & 122 &, \\
Dashgil & MV & 1.4 & 220 & 623 & 843 & 600 & " \\
Yanardag & DS & $>0.01$ & 233 & - & 68 & 6800 & " \\
Bakhar & MV & 0.7 & 36.5 & 8.4 & 45 & 64 &, \\
\multicolumn{2}{r}{ Total measured } & 5.9 & & & 1392 & &, \\
\hline
\end{tabular}

Table III. Comparison of methane emission estimates between Romania, Sicily and Azerbaijan.

\begin{tabular}{cccccc}
\hline \hline Location & Degassing intensity & $\begin{array}{c}\text { Surface } \\
\left(\mathrm{km}^{2}\right)\end{array}$ & $\begin{array}{c}\text { Specific flux } \\
\left(\mathrm{t} \mathrm{km}^{-2} \mathrm{y}^{-1}\right)\end{array}$ & $\begin{array}{c}\text { Total output } \\
\left(\mathrm{t} \mathrm{y}^{-1}\right)\end{array}$ & References \\
\hline \multirow{2}{*}{ Sicily } & High & 1.4 & 280 & 400 & Etiope et al. $(2002)$ \\
Azerbaijan & High & $720-1200$ & $400-800$ & $0.3-0.9 \times 10^{6}$ & Etiope et al. $(2004 \mathrm{~b})$ \\
& Low & $480-800$ & $100-200$ & & \\
Romania & High & $2.5-3$ & $500-600$ & $1500-2500$ & This work \\
& Low & $1.5-3$ & $100-200$ & & \\
\hline
\end{tabular}

Both the high helium content and ${ }^{3} \mathrm{He} /{ }^{4} \mathrm{He}$ ratio measured in the Homorod gases give new constraints on the deep gas origin, indicating a contribution of mantle-derived helium. We may estimate the percentage of mantle-derived helium using the approach based on the measured ${ }^{3} \mathrm{He} /{ }^{4} \mathrm{He}$ and ${ }^{4} \mathrm{He} /{ }^{20} \mathrm{Ne}$ ratios (Sano et al., 1982).
In view of the fact that the investigated manifestations fall in a continental area, we assume two possible mantle end-members, a sub-continental lithospheric mantle (SCLM), with a helium isotope ratio of $6.1 \pm 0.9 \mathrm{Ra}$ (Gautheron and Moreira, 2002), and a MORB-type source ( $8 \pm 1$ Ra; Farley and Neroda, 1998). A mantle-de- 
rived contribution up to $10 \%$ is derived for the Homorod gas.

No direct measurement of helium flux has been carried out; even though we may compute the mantle helium flux following the method proposed by O'Nions and Oxburgh (1988). Assuming that helium degasses across a segment of crust under steady state conditions, its isotope signature comes from the local mantle helium flux (O'Nions and Oxburgh, 1988). Besides the helium flux data of the continental crust adopted by O'Nions and Oxburgh (1988), we considered two possible mantle end-members: a MORB-type source and a sub-continental lithospheric mantle (SCLM). Whatever the deep end-member is, the resulting Homorod mantle-derived helium flux is up to one order of magnitude higher than that of a stable continental area $\left(2.8 \times 10^{7}\right.$ atoms $\mathrm{m}^{-2} \mathrm{~s}^{-1}$; O'Nions and Oxburgh, 1983) implying an active role of the deep tectonic discontinuities in transferring fluids through the crust towards the surface.

Further investigations, including $\mathrm{CH}_{4}$ and $\mathrm{N}_{2}$ isotopic analyses, may provide better constrains to the origin of the gas phase, its relation with hydrocarbon reservoirs, regional Quaternary magmatism, deep faults and heat flow.

\subsection{Updating methane emission estimate}

Areas with higher specific fluxes of methane correspond to dry macro-seeps (Sarmasel, An- dreiasu) and large dimension mud volcanoes (e.g., Paclele Mari, Paclele Mici), related to the main oil and gas reservoirs existing in Romania. Very high methane fluxes (2000 to $3000 \mathrm{t} \mathrm{km}^{-2} \mathrm{y}^{-1}$, up to $125000 \mathrm{t} \mathrm{km}^{-2} \mathrm{y}^{-1}$ over limited degassing zones) are released by dry macro-seeps of small dimensions (hundreds to thousands of $\mathrm{m}^{2}$ ), but generating everlasting fires and high diffuse flux throughout large areas.

The highest mud volcano gas fluxes are in the range of 500-600 $\mathrm{t} \mathrm{km}^{-2} \mathrm{y}^{-1}$ trough mud volcano area from 2.5 to $3 \mathrm{~km}^{2}$. These fluxes are comparable to those measured in other parts of the world (Etiope et al., 2003, 2004a), and slightly higher than that of most of the Azeri mud volcanoes during quiescent periods (Etiope et al., 2004b). Only the «Dashgil type» structures constantly release fluxes similar to those of the large Romanian mud volcanoes (see table III).

Lower methane fluxes $\left(100-200 \mathrm{t} \mathrm{km}^{-2} \mathrm{y}^{-1}\right)$ were measured in a small $\mathrm{N}_{2}$-dominant mud volcano (Homorod), characterised by weaker water discharge, almost flat edifices or small pools. The total surface occupied by low degassing structures on the Romanian territory is estimated in the range of 1.5 to $3 \mathrm{~km}^{2}$.

Assuming the three degassing levels as emission factors, i.e. 2000 to $3000 \mathrm{t} \mathrm{km}^{-2} \mathrm{y}^{-1}$ (dry macro-seeps), 500-600 $\mathrm{t} \mathrm{km}^{-2} \mathrm{y}^{-1}$ (large mud volcanoes) and 100-200 $\mathrm{t} \mathrm{km}^{-2} \mathrm{y}^{-1}$ (small mud volcanoes) and knowing the respective degassing areas (table II), the total output of methane from macroseepage in Romania can be

Table IV. Composition (\% v/v) of natural gas in the main reservoirs of Eastern Transylvania (from Filipescu and Huma, 1979).

\begin{tabular}{cccccc}
\hline \hline $\begin{array}{c}\text { Structure name/ } \\
\text { distance from Homorod }\end{array}$ & $\mathrm{CH}_{4}$ & $\mathrm{~N}_{2}$ & $\mathrm{CO}_{2}$ & $\mathrm{He}$ & $\mathrm{H}_{2}$ \\
\hline $\begin{array}{c}\text { Beia } \\
15 \mathrm{~km} \mathrm{NW}\end{array}$ & $80.8-87.6$ & $11.3-17.5$ & $0.5-0.58$ & $0.05-0.114$ & 0.028 \\
$\begin{array}{c}\text { Tarcesti } \\
40 \mathrm{~km} \mathrm{~N}\end{array}$ & $23.6-77.9$ & $3.5-20.2$ & $2.2-72.8$ & $0.017-0.21$ & $0.012-0.017$ \\
$\begin{array}{c}\text { Praid } \\
60 \mathrm{~km} \mathrm{~N} \\
\text { Bentid }\end{array}$ & 39.4 & 57.1 & 0.35 & 0.5 & - \\
$40 \mathrm{~km} \mathrm{~N}$ & $6.2-15.7$ & $4.4-13.2$ & $70.9-89.3$ & $0.056-0.11$ & $0.16-0.2$ \\
\hline
\end{tabular}


conservatively estimated to be in the range 1500-2500 t $\mathrm{y}^{-1}$. Preliminary data have also shown that invisible microseepage occurs throughout large areas, suggesting that the total output of methane from the Romanian territory to the atmosphere is actually much higher.

\section{Acknowledgements}

The paper benefit of the revisions given by F. Yang and an anonymous reviewer whose criticisms and suggestions greatly improved the earlier version of the manuscript. This work was partially supported by NATO funds (contract EST.CLG.977422) and performed as part of the CARBODIN project, within the CEEX Programme, funded by the Romanian Ministry of Education and Research.

\section{REFERENCES}

BAciu, C. and G. ETIOPE (2005): Mud volcanoes and seismicity in Romania, in Mud volcanoes, Geodynamics and Seismicity, edited by G. MARTINELli and B. PANAHI, NATO series (Springer Verlag Berlin), 77-87.

Ballentine, C.J. and B. Sherwood Lollar (2002): Regional groundwater focusing of nitrogen and noble gases into the Hugoton-Panhandle giant gas field, U.S.A., Geochim. Cosmochim. Acta, 66 (14), 2483-2497.

Baylis, S.A., S.J. CaWley, C.J. Clayton and M.A. Savell (1997): The origin of unusual gas seeps from onshore Papua New Guinea, Mar. Geol., 137, 109-120.

ETIOPE, G. and R.W. KLUSMAN (2002): Geologic emissions of methane to the atmosphere, Chemosphere, 49, 777-789.

Etiope, G. and A. Milkov (2004): A new estimate of global methane flux from onshore and shallow submarine mud volcanoes to the atmosphere, Environ. Geol., 46, 997-1002.

Etiope, G., A. Caracausi, R. Favara, F. Italiano and C. BACIU (2002): Methane emission from the mud volcanoes of Sicily (Italy), Geophys. Res. Lett., 29 (8), 56,156,4, doi: 10.1029/2001GL014340.

Etiope, G., A. Caracausi, F. Italiano, R. Favara and C. BACIU (2003): Reply to comment by A. Kopf on «Methane emission from the mud volcanoes of Sicily (Italy)» and notice on $\mathrm{CH}_{4}$ flux data from European mud volcanoes, Geophys. Res. Lett., 30 (2), 1094, doi: 10.1029/2002GL016287.

Etiope, G., C. Baciu, A. Caracausi, F. Italiano and C. CosMA (2004a): Gas flux to the atmosphere from mud volcanoes in Eastern Romania, Terra Nova, 16, 179-184.

Etiope, G., A. Feyzullayev, C.L. Baciu and A.V. Milkov (2004b): Methane emissions from mud volcanoes in Eastern Azerbaijan, Geology, 32 (6), 465-468.

Farley, K.A. and E. Neroda (1998): Noble gases in the Earth's mantle, Annu. Rev. Earth Planet. Sci., 26, 189-218.
Gautheron, C. and M. Moreira (2002): Helium signature of the subcontinental lithospheric mantle, Earth Planet. Sci. Lett., 199 (1-2), 39-47.

Guseva, A.N. and L.A. FAYngersh (1973): Conditions of accumulation of nitrogen in natural gases as illustrated by the Central European and Chu-Sarysu oil-gas basins, Dokl. Akad. Nauk SSSR, 209 (2), 210-212.

FiliPESCU, M.N. and G. Huma (1979): Geochemistry of Natural Gases (Acad. Publ. House, Bucharest), p. 175 (in Romanian).

Hovland, M., A. HiLl and D. Stokes (1997): The structure and geomorphology of the Dashgyl mud volcano, Azerbaijan, Geomorphology, 21, 1-15.

Huismans, R.S., G. Bertotti, D. Ciulavu, C.A.E. SanDERs, S. Cloetingh and C. Dinu (1997): Structural evolution of the Transylvanian Basin (Romania): a sedimentary basin in the bend zone of the Carpathians, Tectonophysics, 272, 249-268.

ISEKI, T. (2004): A portable remote methane detector using an InGaAsP DFB laser, Env. Geology, 46 (8), 10641069.

Kopf, A.J. (2002): Significance of mud volcanism, Rev. Geophys., 40 (2), pp. 52, doi: 10.1029/2000RG000093.

Krooss, B.M., R. Littke, B. Muller, J. Frielingsdorf, K. SCHWOCHAU and E.F. IDIZ (1995): Generation of nitrogen and methane from sedimentary organic matter: implications on the dynamics of natural gas accumulations, Chem. Geol., 126, 291-318.

LiNK, W.K. (1952): Significance of oil and gas seeps in world oil exploration, AAPG Bull., 36, 1505-1540.

LinZer, H.-G., W. Frisch, P. Zweigel, R. Garbacea, H.-P. HANN and F. Moser (1998): Kinematic evolution of the Romanian Carpathians, Tectonophysics, 297, 133-156.

Motyka, R.J., R.J. PoredA and W.A. JEFFREy (1989): Geochemistry, isotopic composition, and origin of fluids emanating from mud volcanoes in the Copper River Basin Alaska, Geochim. Cosmochim. Acta, 53, 29-41.

O'Nions, R.K. and E.R. OxBURGH (1983): Heat and helium in the Earth, Nature, 306, 429-431.

O'Nions, R.K. and E.R. OxBURGH (1988): Helium, volatile fluxes and the development of continental crust, Earth Planet. Sci.Lett., 90, 331-347.

Paraschiv, D. (1979): Romanian oil and gas fields, Inst. Geol. Geophys. Tech. Ec. St. Ec., 13, 5-382.

PARAschiv, D. (1984): On the natural degasification of the hydrocarbon-bearing deposits in Romania, An. Inst. Geol. Geofiz., LXIV, 215-220.

Peaha, M. (1965): The mud volcanoes from Romania, St. Cerc. Geol., Geofis., Geogr. (Geogr.), 12 (2), 193-206 (in Romanian).

SANO, Y., T. Tominaga, Y. NAKAmURA and H. WAKita (1982): ${ }^{3} \mathrm{He} /{ }^{4} \mathrm{He}$ ratios of methane-rich natural gases in Japan, Geochem. J., 16, 237-245.

Sencu, V. (1985): Mud Volcanoes from Berca (Sport-Turism Publ. House, Bucharest), pp. 21 (in Romanian).

Vaselli, O., A. Minissale, F. Tassi, G. Magro, I. Seghedi, D. IOANE and A. SzAKACS (2002): A geochemical traverse across the Eastern Carpathians (Romania): constraints on the origin and evolution of the mineral water and gas discharges, Chem. Geol., 182, 637-654.

YANG, T.F., C.Y. Chou, C.H. ChEN, L.L ChyI and J.H. JIANG (2003): Exhalation of radon and its carrier gases in SW Taiwan, Radiat. Meas., 36, 425-429. 